\title{
A HISTOLOGICAL STUDY OF THE ARTERIOLES OF THE MUSCLE AND SKIN FROM THE ARM AND LEG IN INDIVIDUALS WITH COARCTATION OF THE AORTA
}

\author{
By ASHTON GRAYBIEL, ARTHUR W. ALLEN and PAUL D. WHITE
}

(From the Cardiac Clinics and Laboratory, Massachusetts General Hospital, Boston)

There is a form of arteriosclerosis termed diffuse hyperplastic sclerosis which is associated with arterial hypertension. It involves especially the arterioles and smaller arteries and its distribution among the organs is characteristic. It most commonly affects the kidney and spleen, less commonly the pancreas, liver and brain, and rarely, the myocardium, skin, or gastro-intestinal tract. Jores (1), Fahr (2), Evans (3), and Fishberg (4) report that it rarely if ever occurs in voluntary muscle. On the other hand Kernohan, Anderson and Keith (5), in studying the arterioles of voluntary muscle from cases of benign or malignant hypertension, observed pronounced changes which included hypertrophy of the media, intimal proliferation, and reduction in the ratio of lumen to wall. Their observations were confirmed by Barber, Keith and Kernohan (6), and by Pilcher and Schwab (7).

The purpose of this study was to determine whether the pathological changes described by Kernohan et al. (5) are found in certain of the arterioles of voluntary muscle from individuals with coarctation of the aorta of the adult type. In this congenital anomaly the bearer suffers hypertension above the stenosis and hypotension below. Therefore, from the skin and muscle of the same individual, one can select for study small arteries of skin and muscle that have been subjected for long periods to quite different blood pressures.

\section{CLINICAL FINDINGS IN OUR CASES}

Five individuals, two male and three female, varying in age from 20 to 33 years, were studied. In four, coarctation of the aorta was the only physical abnormality revealed by careful clinical and laboratory study, while in one there were present in addition a duodenal ulcer and a moderate secondary anemia. Two had slight dyspnea, and one of these had slight numbness of the legs on exercise. Increased arterial pulsations in the neck and markedly decreased arterial pulsations in the lower extremities were findings common to all. There was a loud systolic murmur in each case, best heard over the base of the heart, and well transmitted over the upper thoracic spine; in two instances slight diastolic murmurs also were heard along the upper left sternal border. The aortic second sound was in all cases louder than the pulmonic second. Enlarged and pulsating intercostal arteries in the posterior aspect of the chest were noted in each case. Roentgenological findings were characteristic: the heart was enlarged in three cases and within normal limits in two ${ }^{1}$; there was a fading away or notching of the aortic arch in three; all showed scalloping of the lower rib borders. Electrocardiograms were not remarkable. The average

1 Lewis (8) has shown that the heart may be definitely hypertrophied in individuals with coarctation of the aorta even though the roentgenological measurements are normal.

TABLE I

Showing age, sex, and average blood pressures in the 5 cases

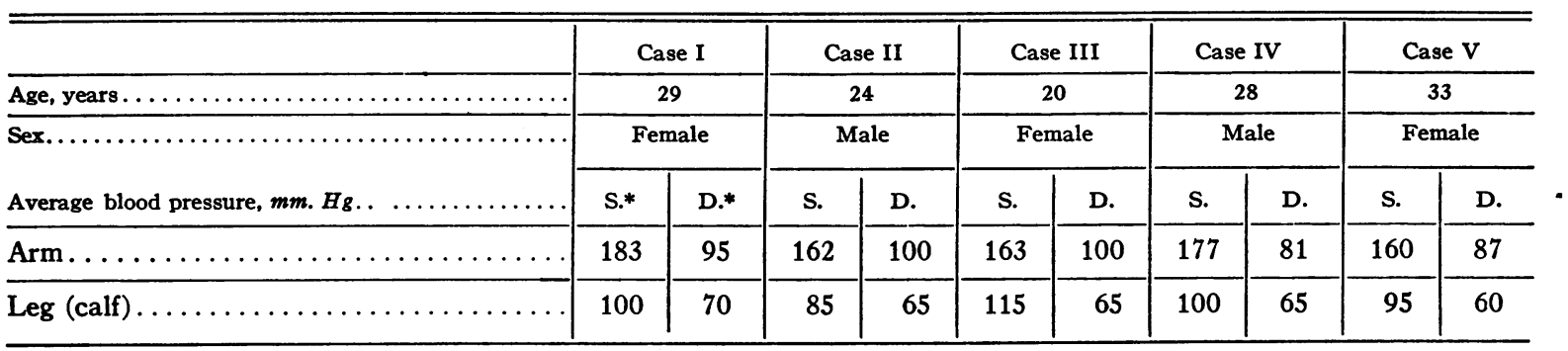

* S-systolic, D-diastolic. 
arterial blood pressures, taken with the patient recumbent, are shown in Table I; the Pachon oscillometer was used for all of the measurements from the leg and some of those from the arm.

While the blood pressures proximal to the coarctation were not very high the increase in pressure in these vessels during exercise or emotion was greater than normal and systolic readings over $220 \mathrm{~mm}$. Hg were usual on such occasions.

It is significant that arteriosclerosis of the retinal arteries was present in two cases and early sclerotic changes in one other. O'Hare and Walker (9) have shown that closely associated with arterial hypertension is retinal arteriosclerosis rather than senile arteriosclerosis of the peripheral arteries, and we believe the hypertension to be causally related to the retinal sclerosis in our cases.

\section{METHOD OF STUDY}

A block of muscle 1 by $2 \mathrm{~cm}$., with the overlying skin and subcutaneous tissue, was removed for examination from the deltoid and gastrocnemius muscle of each patient. Each specimen was at once divided and one part fixed in formalin and the other part in Zenker's solution. Sections from each piece were stained with eosin methylene blue, Mallory's aniline blue, Mallory's phosphotungstic acid, Van Gieson's and Scharlach R stains. Each section was examined for visible pathological changes in or around the blood vessels. With a micrometer eyepiece, an $\times 10 \mathrm{ocu}-$ lar, and an $\times 90$ objective, the arterioles and smallest arteries, cut in nearly perfect crosssection, were measured. Two diameters of the cross section of the artery bisecting each other at right angles were selected and the ratio between average thickness of lumen and of wall was calculated; the value for the wall was taken as 1 . In each case the ratios obtained for the vessels of the skin and muscle of the arm were compared respectively with those of the leg.

An effort was made to establish criteria for the selection of arterioles. Evans (3) used the word arteriole for the smallest arterial twigs with media of 2 or 3 muscle cells in thickness. Kernohan et al. (5) used the term for arteries from 25 to 100 microns in outside diameter. Evans (3) has shown that in the kidney the pathological changes in the arterioles differ in character from those in the arteries from which the arterioles spring. Here at least is an opportunity for distinguishing them based on pathological findings. We measured the afferent arterioles of normal glomeruli, in sections prepared as were those used in this study, and found the great majority of these arterioles had outside diameters between 20 and 30 microns. We have accordingly classified as arterioles those arteries in fixed tissue which are less than 30 microns across while those between 30 and 100 microns across we have classified as "smallest arteries." Allowing 40 per cent for shrinkage in preparation, the arterioles would measure not more than 50 microns under physiological conditions. Obviously, if certain arterioles are thickened by pathological changes some may exceed our arbitrary limit for size; moreover contraction of a small artery during removal and fixation may be sufficient to result in its being classified wrongly as an arteriole. However, definition by measurement will best convey to others the size of artery under consideration.

\section{MICROSCOPICAL FINDINGS}

The arteries, veins and capillaries of each biopsied tissue were studied microscopically but no pathologically significant changes were found in any. Very occasionally one of the smallest arteries or arterioles showed slight thickening of the intima, slight proliferation of the endothelial cells lining the lumen, and a puckering or undulation of the internal elastic membrane. The slight intimal thickening was characteristically uniform around the circumference of the vessel and the lumen was never greatly encroached upon or narrowed. This appearance was sometimes studied further by tracing the vessel serially into sections differently stained. It was interpreted by us as indicating unequivocally a normal vessel slightly contracted. The proliferation of the lining endothelial cells and the puckering of the internal elastic membrane were associated with and, we thought, most reasonably explained by medial contraction. The degree of this contraction varied among the arteries of similar size in the same section, and could be gauged most readily by the degree of undulation of the internal elastic membrane. These apparent abnormalities were seen in vessels from both skin and muscle and with 
TABLE II

Showing the number of vessels measured, their diameters and ratios of thickness of lumen to thickness of wall

\begin{tabular}{|c|c|c|c|c|c|c|c|c|c|}
\hline & & \multicolumn{2}{|c|}{$\begin{array}{c}\text { Number of vessels } \\
\text { measured }\end{array}$} & \multicolumn{2}{|c|}{$\begin{array}{l}\text { Average outside } \\
\text { diameter }\end{array}$} & \multicolumn{2}{|c|}{$\begin{array}{l}\text { Extreme ratios } \\
\text { lumen to wall }\end{array}$} & \multicolumn{2}{|c|}{$\begin{array}{l}\text { Average ratios } \\
\text { lumen to wall }\end{array}$} \\
\hline & & Arterioles & $\begin{array}{l}\text { Smallest } \\
\text { arteries }\end{array}$ & Arterioles & $\begin{array}{l}\text { Smallest } \\
\text { arteries }\end{array}$ & Arterioles & $\begin{array}{l}\text { Smallest } \\
\text { arteries }\end{array}$ & Arterioles & $\begin{array}{c}\text { Smallest } \\
\text { arteries }\end{array}$ \\
\hline \multirow{4}{*}{ Case I } & Muscle of arm & 14 & 9 & $\begin{array}{c}\text { microns } \\
18.8\end{array}$ & $\begin{array}{c}\text { microns } \\
45.3\end{array}$ & $\begin{array}{l}1.55 \\
3.52\end{array}$ & $\begin{array}{l}1.69 \\
3.37\end{array}$ & 2.16 & 2.60 \\
\hline & Muscle of leg & 7 & 2 & 20.3 & 38.2 & $\begin{array}{l}1.70 \\
2.80\end{array}$ & $\begin{array}{l}1.81 \\
2.18\end{array}$ & 2.20 & 1.99 \\
\hline & Skin of arm & 1 & & 10.0 & & 2.18 & & 2.18 & \\
\hline & Skin of leg & 21 & 1 & 19.1 & 27.6 & $\begin{array}{l}1.44 \\
3.11\end{array}$ & 2.18 & 2.21 & 2.18 \\
\hline \multirow{4}{*}{ Case II } & Muscle of arm & 6 & 5 & 20.1 & 37.2 & $\begin{array}{l}1.57 \\
2.27\end{array}$ & $\begin{array}{l}2.05 \\
2.66\end{array}$ & 1.80 & 2.43 \\
\hline & Muscle of leg & 5 & 3 & 22.3 & 49.2 & $\begin{array}{l}1.42 \\
2.60\end{array}$ & $\begin{array}{l}1.87 \\
3.05\end{array}$ & 2.23 & 2.52 \\
\hline & Skin of arm & 4 & 5 & 21.0 & 48.1 & $\begin{array}{l}1.83 \\
2.26\end{array}$ & $\begin{array}{l}2.25 \\
3.31\end{array}$ & 2.02 & 2.59 \\
\hline & Skin of leg & 2 & & 16.2 & & $\begin{array}{l}2.26 \\
2.49\end{array}$ & & 2.37 & \\
\hline \multirow{4}{*}{ Case III } & Muscle of arm & 9 & 3 & 19.5 & 59.2 & $\begin{array}{l}1.52 \\
2.56\end{array}$ & $\begin{array}{l}2.40 \\
3.70\end{array}$ & 2.07 & 3.07 \\
\hline & Muscle of leg & 3 & 5 & 18.4 & 46.3 & $\begin{array}{l}1.25 \\
2.28\end{array}$ & $\begin{array}{l}1.15 \\
3.21\end{array}$ & 1.84 & 2.41 \\
\hline & Skin of arm & 9 & 2 & 16.3 & 59.6 & $\begin{array}{l}1.58 \\
2.33\end{array}$ & $\begin{array}{l}2.31 \\
2.58\end{array}$ & 1.96 & 2.44 \\
\hline & Skin of leg & 5 & 1 & 20.1 & 39.2 & $\begin{array}{l}1.75 \\
2.25\end{array}$ & 2.00 & 2.01 & 2.00 \\
\hline \multirow{4}{*}{ Case IV } & Muscle of arm & 15 & 2 & 19.0 & 33.8 & $\begin{array}{l}1.91 \\
3.05\end{array}$ & $\begin{array}{l}1.71 \\
3.00\end{array}$ & 2.46 & 2.35 \\
\hline & Muscle of leg & 15 & 1 & 18.2 & 87.2 & $\begin{array}{l}1.46 \\
2.34\end{array}$ & 2.04 & 2.00 & 2.04 \\
\hline & Skin of arm & 7 & & 18.0 & & $\begin{array}{l}1.43 \\
2.33\end{array}$ & & 2.02 & \\
\hline & Skin of leg & 13 & & 19.5 & & $\begin{array}{l}1.36 \\
2.82\end{array}$ & & 2.60 & \\
\hline \multirow{4}{*}{ Case V } & Muscle of arm & 8 & 2 & 17.7 & 93.4 & $\begin{array}{l}1.61 \\
2.62\end{array}$ & $\begin{array}{l}2.72 \\
3.37\end{array}$ & 2.13 & 3.03 \\
\hline & Muscle of leg & 5 & 3 & 17.0 & 64.4 & $\begin{array}{l}1.33 \\
2.19\end{array}$ & $\begin{array}{l}2.00 \\
3.03\end{array}$ & 1.85 & 2.62 \\
\hline & Skin of arm & 8 & & 17.8 & & $\begin{array}{l}1.61 \\
2.38\end{array}$ & & 2.08 & \\
\hline & Skin of leg & 9 & & 16.7 & & $\begin{array}{l}1.70 \\
2.70\end{array}$ & & 2.14 & \\
\hline
\end{tabular}


TABLE III

The findings in Table II summarized and arranged for easy comparison of the determinations made from the vessels of arm and leg

\begin{tabular}{|c|c|c|c|c|c|c|c|c|}
\hline & \multicolumn{4}{|c|}{ Muscle } & \multicolumn{4}{|c|}{ Skin } \\
\hline & \multicolumn{2}{|c|}{ Arterioles } & \multicolumn{2}{|c|}{ Smallest arteries } & \multicolumn{2}{|c|}{ Arterioles } & \multicolumn{2}{|c|}{ Smallest arteries } \\
\hline & Arm & Leg & Arm & Leg & Arm & Leg & Arm & Leg \\
\hline Average outside diameter in microns & 19.0 & 19.2 & 53.7 & 57.1 & 16.6 & 18.3 & 53.8 & 38.4 \\
\hline Extreme ratios lumen to wall & $\begin{array}{l}1.52 \\
3.52\end{array}$ & $\begin{array}{l}1.25 \\
2.80\end{array}$ & $\begin{array}{l}1.69 \\
3.70\end{array}$ & $\begin{array}{l}1.15 \\
3.21\end{array}$ & $\begin{array}{l}1.43 \\
2.38\end{array}$ & $\begin{array}{l}1.36 \\
3.11\end{array}$ & $\begin{array}{l}2.25 \\
3.31\end{array}$ & $\begin{array}{l}2.00 \\
2.18\end{array}$ \\
\hline Average ratios lumen to wall & 2.12 & 2.02 & 2.69 & 2.32 & 2.05 & 2.26 & 2.51 & 2.09 \\
\hline
\end{tabular}

similar frequency in tissues from either the arm or leg. They were considered not pathologically significant.

The ratios for thickness of lumen to thickness of wall were calculated for the arterioles and for the smallest arteries, and those for the vessels of the skin and muscle of the arm were compared, respectively, with those of the leg. These results are given in Tables II and III.

Table II gives the number of arterioles and smallest arteries measured in each tissue, their average diameter, and the extreme and average ratios for thickness of lumen to thickness of wall. While there was considerable variation in these ratios for the arterioles ( 1.25 to 3.52 ), the great majority had a ratio approximating 2 . The average ratios for arteriolar lumen to wall ranged from 1.80 to 2.60. The ratios for " smallest arteries" ranged from 1.15 to 3.70 but the great majority had ratios somewhat greater than 2 . The average ratios for the "smallest arteries" ranged from 1.99 to 3.07 .

Table III is a summary of Table II and gives the averages of the separate values for the 5 cases. It shows clearly that the vessels of the arm and leg were similar with respect to their ratios for thickness of lumen to thickness of wall. The average ratio for the arterioles of the arm muscle was 2.12 and for the leg 2.02 ; the corresponding ratios for the smallest arteries were slightly greater, 2.69 for the arm and 2.32 for the leg.

The above data taken collectively confirmed the visual impression that the vessels studied were normal ; the muscle cells were neither wasted nor hypertrophied and the nuclei were distinct; there was no hyperplasia or splitting of the elastic lam- ina; the intima and the lining endothelial cells were not considered abnormal. There was no hyaline or fatty degeneration.

\section{DISCUSSION}

The increased blood pressure proximal to the coarctation of the aorta in these 5 cases is explicable only on mechanical grounds. While this increase was not very great it was prolonged over a long time and was accompanied by cardiac enlargement in at least three instances and definite retinal arteriosclerosis in two. Distal to the coarctation the blood pressure was conspicuously low and the arteries were not subjected to any strain. Despite this difference in blood pressure, however, the small vessels of the skin and muscle of the arm were similar histologically to those in the leg, and our examination failed to discover any changes pathologically significant.

Our cases differ from those of Kernohan et al. (5) in several respects. First, they belong to a younger age group; it is possible that a similar strain on the arterioles of older individuals would produce pathological changes. Secondly, the degree of hypertension was not so great; a more severe hypertension even though of shorter duration might be more destructive. Thirdly, the hypertension was of known origin in our cases and limited to the upper part of the body whereas in cases with benign or malignant hypertension where the cause remains unknown there may perhaps be some noxious factor damaging the arterioles. Nevertheless our negative findings are of considerable importance in that they rule out slight to moderate degrees of hypertension maintained over long intervals of time as a cause of 
pathological changes in the smallest arteries and arterioles of the voluntary muscle and skin of the arm in young individuals.

\section{SUMMARY}

We have found that the hypertension associated with coarctation of the aorta in 5 young individuals has not caused sclerosis of the arterioles or smallest arteries of the skin or voluntary muscle. In these 5 cases the systolic blood pressure in the arm averaged 70 millimeters more than that in the leg and the diastolic pressure in the arm 28 millimeters more than that in the leg. Nevertheless, it was impossible by biopsy in these cases to distinguish the arterioles and smallest arteries of the arm from those of the leg.

We wish to thank Dr. Tracy B. Mallory for his aid and for the facilities of his laboratory.

\section{BIBLIOGRAPHY}

1. Jores, L., Uber die Arteriosklerose der kleinen Organarterien und ihre Beziehungen zur Nephritis. Virch. Arch. f. path. Anat., 1904, 178, 367.
2. Fahr, T., Zur pathologisch-anatomischen Unterscheidung der Schrumpfnieren nebst Bemerkungen zur Arteriosklerose der kleinen Organarterien. Frankfurt. Ztschr. f. Path., 1912, 9, 15.

3. Evans, G., A contribution to the study of arteriosclerosis with special reference to its relation to chronic renal disease. Quart. J. Med., 1920-1921, 14, 215.

4. Fishberg, A. M., Anatomic findings in essential hypertension. Arch. Int. Med., 1925, 35, 650.

5. Kernohan, J. W., Anderson, E. W., and Keith, N. M., The arterioles in cases of hypertension. Arch. Int. Med., 1929, 44, 395.

6. Barber, N. W., Keith, N. M., and Kernohan, J. W., Arterioles in hypertensive disease. Proc. Staff. Meet. Mayo Clinic, 1931, 6, 172.

7. Pilcher, J. F., and Schwab, E. H., Arteriolar changes in essential hypertension. A preliminary report. Texas State J. Med., 1933, 28, 665.

8. Lewis, T., Material relating to coarctation of the aorta of the adult type. Heart, 1931-33, 16, 205.

9. O'Hare, J. P., and Walker, W. G., Arteriosclerosis and hypertension. Arch. Int. Med., 1924, 33, 343. 